\title{
Research on Trade Effect to Establish Sino- Russian Free Trade Area (FTA) on the Basis of the Partial Equilibrium Model Yi-jun XIANG ${ }^{1}$, $\mathrm{Li} \mathrm{TIAN}^{2,{ }^{*}}$ and Nan $\mathrm{YAN}^{3}$ \\ ${ }^{1}$ Harbin University of Commerce, Harbin 150028, China xiangyj@hrbcu.edu.cn \\ ${ }^{2}$ Harbin University of Commerce, Harbin 150028, China 706060289@foxmail.com \\ ${ }^{3}$ Harbin University of Commerce, Harbin 150028, China 83566986@qq.com
}

Keywords: Sino-Russia FTA, Trade intensity index, Trade effect.

\begin{abstract}
On the background of new economic normality, the regional cooperation between China and Russia has got rapidly developed. Russia is the important country of the "one belt and one road" line, and to establish free trade area is the main propulsive forms of "one belt and one road". The paper analyzes the trade effect of setting up Sino-Russian Free Trade Area (FTA). It includes trade create effect and trade transfer effect between China and Russia in partial equilibrium analysis, SinoRussia trade intensity index calculation, for the purpose of setting up Sino-Russia FTA to governments. It can get the following conclusions: in terms of trade intensity index, Russia is more dependent on the Chinese market; Russia achieves more trade creation effect from Sino-Russian Free Trade Area than that China obtain; the comprehensive trade effect of Sino-Russian FTA is positive.
\end{abstract}

\section{Introduction of Sino-Russian Trade Situation}

As the success of Russia accessing to WTO in 2011, the economic and trade cooperation between China and Russia will launch on more standardized platform. According to China customs data, 2014, Sino-Russian bilateral imports and exports of goods amounted to 95.28 billion dollars, rose $6.8 \%$. Russian exports to China $\$ 41.60$ billion and Russian imports to China $\$ 53.68$ billion, we were balance of $\$ 12.08$ billion. China has become Russia's second-largest export market and the largest source of imports in 2014. Under the strong advocates of China and Russia leaders, "the two multi-billion dollar" goal will be accomplish, that is the trade volume between China and Russia will reach $\$ 100$ billion in 2015 , to the year of 2020 trade volume will exceed \$200 billion. In May of 2014, Russia President Putin's visit to China strengthened the comprehensive strategic partnership of cooperation into a new level between two countries. On 21 of May, Sino-Russia signed a bill of $\$ 400$ billion in natural gas sales-purchase agreement. These all have laid a solid foundation for the establishment of Sino-Russian FTA. In 2014, after the crisis of Ukraine broke out, Russian economy was hit by the sanctions of United States or European countries. It's necessary to speed up the development of the Far East and expand economic cooperation with Asia-Pacific countries. Therefore, China and Russia establish FTA accords with the long-term interests and mutual interest of both sides. 


\section{Sino-Russian Trade Intensity Index Analysis}

Bilateral trade intensity between China and Russia is stable and showed a trend of increase. In order to measure the importance of the bilateral trade relationship, Brown (1949) and KeJiMa (1964) for the first time, puts forward the concept of trade intensity, Lars and Dyer who (1982) on the basis of the derived a formula, i to $j$ countries' export trade intensity index are as follows:

$$
I_{i j}=\left(X_{i j} / M_{j}\right) /\left[X_{i} /\left(M_{w}-M_{i}\right)\right] .
$$

Among equation $1, X_{i j}$ means the country of $i$ to $j$ export; $X_{i}$ means the country $i$ to $j$ total export; $M_{j}$ means country $j$ total imports; $M_{w}$ means the world's total imports; $M_{i}$ means country $i$ total imports. The formula showed $i$ to $j$ 's export on the proportion of total imports and besides i country, the rest countries' import on the proportion of total import.

Table 1 shows the foreign trade turnover between China and Russia in the five past years from 2010 2014. On the whole, Sino-Russian trade increased from $\$ 55.45$ billion in 2010 to $\$ 95.28$ billion in 2014 with the rate of $71.8 \%$. In 2011 , the trade volume was $\$ 79.25$ billion, which Russia exported to China was $\$ 40.35$ billion and grown by $73.3 \%$. Sino-Russian trade volume became more stable in 2012. In 2013, due to the global economic downturn, Europe's debt unknown, the global oversupply of oil and other factors, Russian economy was depressed. So Sino-Russian bilateral trade volume rose less, especially for Russian imports decreased by $10.1 \%$, we were balance of $\$ 9.97$ billion.

Table 1. 2010 2014 Sino-Russia Foreign Trade Volume Unit: [million dollars; \%]

\begin{tabular}{cccccccc}
\hline Year & $\begin{array}{r}\text { Trade } \\
\text { volume }\end{array}$ & $\begin{array}{c}\text { Increase } \\
\text { percent }\end{array}$ & $\begin{array}{c}\text { Export } \\
\text { volume }\end{array}$ & $\begin{array}{r}\text { Increase } \\
\text { percent }\end{array}$ & $\begin{array}{c}\text { Import } \\
\text { volume }\end{array}$ & $\begin{array}{r}\text { Increase } \\
\text { percent }\end{array}$ & $\begin{array}{c}\text { Trade } \\
\text { balance }\end{array}$ \\
\hline 2010 & 554.5 & 43.1 & 296.1 & 69.0 & 258.4 & 21.7 & 27.7 \\
2011 & 792.5 & 40.8 & 389.0 & 23.9 & 403.5 & 73.3 & -14.5 \\
2012 & 881.6 & 11.2 & 441.1 & 13.4 & 440.5 & 9.9 & -2.3 \\
2013 & 892.1 & 1.1 & 495.9 & 12.6 & 396.2 & -10.1 & 99.7 \\
2014 & 952.8 & 6.8 & 436.8 & 8.2 & 416.0 & 4.9 & 120.8 \\
\hline
\end{tabular}

Data sources: China's min istry of commerce website.

Based on the relevant data to formula 1, we can calculate Russia to China and China to Russia trade intensity index. The figures can be seen from Table 2.

Table 2. Trade intensity index between China and Russia during 2009-2014

\begin{tabular}{ccccccc}
\hline Trade intensity index & 2009 & 2010 & 2011 & 2012 & 2013 & 2014 \\
\hline Russia to China & 0.91 & 1.05 & 1.12 & 1.34 & 1.32 & 1.52 \\
China to Russia & 1.03 & 1.36 & 1.24 & 1.26 & 1.28 & 1.34 \\
\hline
\end{tabular}

Data sources: the report data is from China's ministry of commerce, the total import and export of the two countries and the world's import come fro m the WTO's official website.

According to the trade intensity, the meaning of 1 is as a measure of whether the trade relations between two countries close enough. If over 1 , it shows the country $j$ 
depends on country $\mathrm{i}$ more; if under 1 , it shows country $\mathrm{j}$ depend s on country $\mathrm{i}$ less. We can see from Table 2, the two countries trade strength in addition less than 1 in 2009 , all the other years is over 1 . The intensity of trade between the two countries in general rise, though rising rate is slow, but also explain the tightness of the two countries. It show be noticed that the intensity of China to Russia's trade value are relatively stable. That means China in Russia's trade status is more important than Russia in China's trade status. In 2012, China is Russia's fourth largest export market and second largest source of imports. In 2013, under the influence of the Russian economy, China has become Russia's sixth largest export market and the largest source of imports; China is Russia's second largest export market in 2014, the largest source of imports. Russia is extremely dependent on the Chinese market, to satisfy the domestic demand of mechanical and electrical products, textiles and raw materials, base metals and products and light industrial products.

As we can see the data in Table 2, the establishment of free trade zone between China and Russia is necessary. Russia to China's trade dependence is strong and SinoRussian trade intensity index is high. Analysis from this aspect of Sino-Russian trade intensity index, it has the solid trade foundation to establish free trade zone between China and Russia, and the establishment of Sino-Russian FTA will make the two countries to achieve mutual benefit and win-win results.

\section{The Establishment of Partial Equilibrium Analysis Model}

The trade effects of establishing Sino-Russian FTA include trade create effect and trade transfer effect, while the trade effect of plus or minus depends on the sum of the trade create effect and trade transfer effect, that is the result of the comprehensive action of both. Therefore, it's necessary to analyze the trade create effect and trade transfer effect theory and then to calculate.

\section{Partial Equilibrium Model Theoretical Analysis}

Figure 1 shows the partial equilibrium analysis of trade create effect and trade transfer effect of the establishment of Sino-Russian FTA. The horizontal axis stand for China's import demand for Product A, the vertical axis represents import price of Product $\mathrm{A}$, line $\mathrm{S}$ is the supply curve and $\mathrm{D}$ is the demand curve. $\mathrm{Pc}$ is the market price for Product A of China, Pr is the import price of Product A from Russia, Pw represents the price of Product A from other countries, Pt said domestic price when China import Product A from other countries after the import tariff. Before the establishment of Sino-Russian FTA, China imports Product A from other countries, the demand is $\mathrm{MN}$, the price is $\mathrm{Pt}$, and government tariff revenue is $(\mathrm{a}+\mathrm{c})$. After the establishment of Sino-Russian FTA, the tariff on Product A is canceled, the price Pr for China imports Product A from Russia is lower than the price Pt for other countries, China's demand for Product A will import from Russia to meet, then domestic price down to Pr and imports increased from MN to M1N1, M1M is the import substitution, the welfare of domestic production effect increases $b$. Due to the price is down that lead to the demand increased NN1, which is the consumption effect that promote the welfare adds region d. Trade create effect is the sum of production effect and the consumption effect, namely the area $b+d$. The trade transfer effect is due to economic benefits reducing that causes the decline of government tariff revenue. Before the establishment of Sino-Russian FTA, China imported Product A from other countries, welfare cost was region e; after the establishment of Sino-Russian FTA, the imports transfer to Russia, welfare cost is region $(c+e)$. Because the increase of welfare cost 
that caused the economic benefit down c, namely the trade transfer effect is $\mathrm{c}$. The trade effect of the establishment of Sino-Russian FTA for member is positive or not depends on the result of $(b+d)-c$.

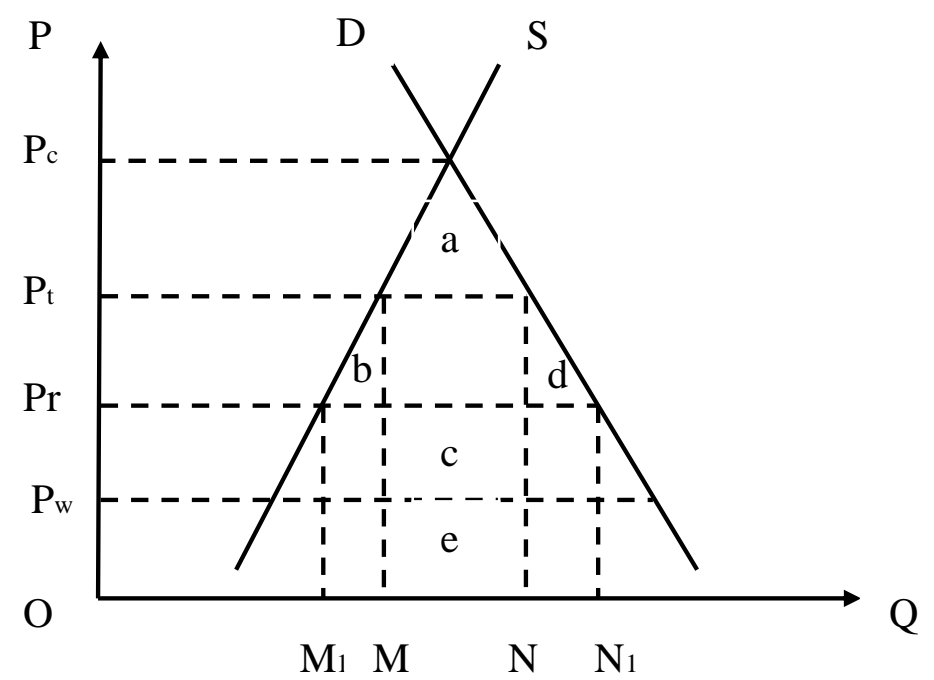

Figure 1 Partial equilibrium analys is of the establishment of Sino-Russian FTA

The assumptions of the model:

(1) Imports from FTA member countries and from non-member states are not entirely substitution;

(2) Imports from member and non-member countries and its domestic production are not fully substitute for;

(3) Trade effects of tariff reduction don't impact the income and the exchange rate;

(4) The supply elasticity of export is infinite, and the trade effect of tariff reduction all reflected in the import price;

Set a constant elasticity of substitution utility function as follows:

$$
\boldsymbol{U}=\left(\sum_{j=1}^{n} \boldsymbol{X}_{j}^{a}\right)
$$

Where: U stands for the utility functions, which means volume of goods imports from $\mathrm{j}$ country. $\mathrm{A}$ is parameter, $(0<a<1)$. The utility function stands for marginal utility of various kinds of imported goods is positive, and showed a decreasing trend. The two kinds of elasticity of substitution $\varepsilon$ is constant, and $\varepsilon=1 /(1-\mathrm{a})$. Based on the assumption that the effects of tariff change passed completely to commodity prices, so the trade create effect can be expressed as:

$$
T C_{a}=\left[\varepsilon+(1-\varepsilon) \mathrm{S}_{\mathrm{a}}\right] \mathrm{Ma}_{\mathrm{a}}\left[\Delta \mathrm{t}_{\mathrm{a}} /\left(1+\mathrm{t}_{\mathrm{a}}\right)\right] .
$$

Where: Ta is the original tariff of importer, $\Delta t_{a}$ is the tariff reductions when FTA is established, $\mathrm{Sa}$ is the share of imports from a country, Ma is import volume from FTA members.

\section{Trade Create Effect}

Trade create effect is the static effects of the FTA, it's also an ex ante analysis. 
Verdoon (1960) and Schwartz(1972) used the method of partial equilibrium analysis of the FTA's trade create analysis, and proposed the partial equilibrium analysis. This paper uses this method to analyze and forecast the trade creation effect of SinoRussian FTA.

\section{The Calculation of the Partial Equilibrium Model}

According to the data from the Chinese Ministry of commerce, in 2014 China imported $\$ 41.6$ billion, which can be seen from Table 3, Minerals, wood and chemical products are the main imports for China from Russia, imports of mineral products: US\$ 28.89 billion and the proportion of total imports was $77.7 \%$. Imports for Russia from China is $\$ 53.68$ billion, the main products are machinery and electronic products, textiles and raw materials and related products, the import volume was US\$23.47 billion, $46.2 \%$ percent of total imports. In 2014, China's overall tariff level for $9.9 \%$, the tariff on Russia's machinery and electronic products was $6.5 \%$, total tariff levels for the average is $13.7 \%$. The total import volume of China was $\$ 2013.65$ billion, as Russia was US\$324.33 billion. Due to the utility for constant elasticity of substitution, Ching-Cheng Chang \& Shih-Hsun Hsu(1999) calculated the trade create effect of east Asian FTA, assumed the domestic import demand elasticity is 2.2, the paper also assumes the $\varepsilon$ is 2.2 .

Table 3. Sino-Russian main imported products and proportion Unit:[\%]

\begin{tabular}{cccc}
\hline $\begin{array}{c}\text { China imported from } \\
\text { Russia }\end{array}$ & proportion & Russia import from & proportion \\
\hline Minerals & 77.7 & Machinery & 46 \\
Woods & 6.8 & Textiles & 9.7 \\
Chemical & 4.0 & Base metals & 7.8 \\
Others & 11.5 & Others & 36.3 \\
\hline
\end{tabular}

Data sources: China's min istry of commerce website country report database.

Through formula 3, when Sino-Russia establishes FTA, the final tariffs down to zero, we can calculate the overall trade create effects and the trade create effects of main product between two countries. The results can be seen from table 4 .

Table 4. Trade create effect for two countries of Sino-Russian FTA Unit: [b illion dollars]

\begin{tabular}{ccc}
\hline volume/country & China & Russia \\
\hline Total trade create & 73.59 & 123.36 \\
Minerals trade create & 56.81 & - \\
Machinery trade create & - & 30.27 \\
\hline
\end{tabular}

The data shows that bilateral trade create effect is above zero, because Russia's average tariff is higher than China's tariff level, So Russia will get more trade create effect than China get from Sino-Russian FTA. This trade create effect is due to the low cost products of the low tax country replace the high cost product result, it comes from two aspects of production and consumption effects. If Sino-Russian FTA is established, low-priced products of higher-productivity countries within the region will inflow to the countries with relatively low productivity, which domestic producers supply will drop. As a result, the resources will be more efficient, then resulting product effect. Consumer effect is due to the low-price products of the 
higher productivity country inflow into the inefficient state, so make the domestic prices of same products which are inefficient to decline, thus consumer surplus of the domestic consumers will increase.

\section{Trade Transfer Effect}

The trade transfer effect of the establishment of Sino-Russian FTA is because the establishment of FTA to form a regular tariff to China and Russia. Thus makes the demand for the same product importing from outside the FTA to regional members, which improved the consumer demand within the area. But due to the production cost is higher in FTA than outside the area, it makes the producers costs increase and consumption decrease, lead to the producer surplus and consumer surplus to reduce, eventually make the welfare level of members in the area decline. Therefore, the result of trade transfer effect is negative.

\section{The Establishment of the Model}

China and Russia are both the world trade country, the textiles and primary products product of China exports to everywhere, Russia is full of energy and exports energy to other countries. The production capacity of the two countries is very strong, so this paper calculates the trade transfer effect of Sino-Russia FTA hypothesis export supply curve for both countries is perfectly elastic. Based on this assumption, the formula of trade transfer effect is:

$\mathrm{TDCR}=\mathrm{TCCR} *(\mathrm{Ma} / \mathrm{VCR})$.

In Formula 4, TDCR stands for the trade transfer effect of the establishment of Sino-Russia FTA; TCCR is the trade creation effect of the establishment of SinoRussia FTA; Ma is the trade import volume for the two countries before Sino-Russian FTA build; VCR said the domestic production of both countries, and usually measure it of a country's GDP.

\section{The Calculation of Trade Transfer Effect}

Firstly, to calculate trade transfer effect of China, according to the data of national statistics bureau, in 2014, China's GDP is $\$ 10.335375$ trillion; the calculation result to Formula 3 of trade create effect is $\$ 7.359$ billion; China imported from Russia is $\$ 41.6$ billion. Assign the data to Formula 4, TDC $=73.59 *(416 / 103353.75)$, the trade transfer effect of China is $\$ 29.62$ million.

Then calculate trade transfer effect of Russia, according to the ministry of commerce of China, in 2014, Russia's GDP is 2.051838 trillion; Russia's trade create effect TCCR is $\$ 12.336$ billion; Russian imports from China is 53.68 billion. Based on the Formula 4, TDR $=123.36^{*}(536.8 / 20518.38)$, it is concluded that Russia's trade transfer effect is $\$ 322.7333$ million.

To establish Sino-Russia FTA will cause positive trade create effect and negative trade transfer effect, the paper uses partial equilibrium analysis to calculate, the results can be seen for Table 5 .

Table 5. Trade create effect and trade transfer effect of Sino-Russian FTA Unit: [million dollars]

\begin{tabular}{lcc}
\hline Country/Volume & Trade create effect & Trade transfer effect \\
\hline China & 7359.0 & 29.62 \\
Russia & 12336.0 & 322.733 \\
\hline
\end{tabular}


We can see from Table 5, China and Russia establish FTA will produce a certain trade transfer, then the welfare level of the member within FTA will reduce, but the trade create effect is far lower than trade create effect. Therefore, the total trade effect of Sino-Russia FTA is positive. After the establishment of Sino-Russian FTA, the total welfare level of the two countries will significantly rise.

\section{Conclusion}

The paper uses the method of partial equilibrium analysis to measure the trade effect of the establishment of Sino-Russian FTA. We can draw the following conclusions: China in Russia trade status is more important than Russia in China's trade status, because Russia's trade dependence on China more than China's trade dependence on Russia. The establishment of free trade zone between China and Russia has positive effect, because the Russian tariff to China, so Russia gained more than China. Moreover, through goods market specialization, which can generate economies of scale, improve the welfare of the local consumers, the two countries' enterprise can obtain scale economic benefits. To promote the regular negotiations and agreements for the two countries of setting up Sino-Russian FTA, the paper put forward the following suggestions. Firstly, take full advantages of China and Russia economic complementary superiority, deepen Sino-Russian trade and economic cooperation and expand the trade scale, optimizing the trade structure. Secondly, pay more attention to the border cooperation between two countries, focus on the development of far east of Russia and northeastern of China resources and energy cooperation, and to revitalize northeast old industrial base, then gradually perfect the pattern of China 's opening to the outside; finally, to speed up infrastructure construction between China and Russia, to create "economic corridor "longjiang road construction of ribbon, for the establishment of Sino-Russian FTA to provide the material basis.

\section{Ackno wledge ment}

This research was financially supported by Harbin University of Commerce graduate student innovation of scientific research funds (YJSCX2015-350HSD) and humanities and social science project of Education Department (2013WK0145)

\section{References}

[1] Michael Bwrawoy. The state and economic involution: Russia through a China lens. [J].World Development, 1996, 24 (6)

[2] EL Nichols Jr, JC Taylor, Sourcing implications of the North American free trade agreement, Journal of Supply Chain Management [J].2006, 15(6)

[3] Bull Kasahara, Brazil and China: partners or competitors, Centre for Development and the Environment, [J].2011, 10(3)

[4] Han Dongxue. The empirical study of factors which affecting China-Russian trade. [J]. Journal of Shandong social science. 2012(3): 31 33. In Chinese

[5] Li Yanli. The research of political and economic analysis between China free trade area. [M]. 2012. In Chinese

[6] Information on http://www. fdi.gov.cn

[7] Information on http//www. mofcom.gov.cn 